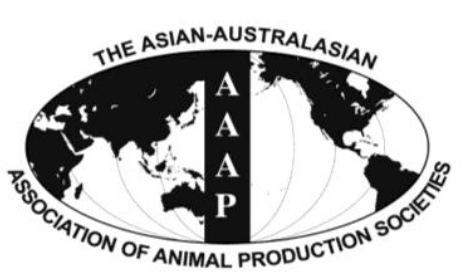

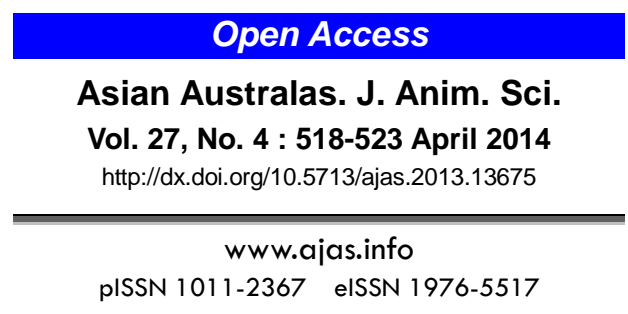

\title{
Growth Performance and Carcass Characteristics of Korean Native Ducks Fed Diets with Varying Levels of Limiting Amino Acids
}

\author{
Y. K. Choo, H. J. Kwon, S. T. Oh, C. W. Kang, H. K. Kim ${ }^{1}$, E. C. Hong ${ }^{1}$, K. N. Heo ${ }^{1}$, S. K. Lee ${ }^{2}$, and B. K. An* \\ Department of Animal Science and Technology, Konkuk University, Seoul 143-701, Korea
}

\begin{abstract}
There are multiple experiments conducted with male Korean native ducks (KND) to evaluate the optimal levels of limiting amino acids (AA). In Exp. 1, a total of 450 one-d-old male KNDs were divided into five groups with six replicates and fed experimental diets with varying levels of lysine, total sulfur amino acids (TSAA) and threonine (T1, 0.90/0.74/0.70\%; T2, 1.00/0.82/0.77\%; T3, 1.10/0.90/0.85\%; T4, 1.20/0.98/0.93\%; T5, 1.30/1.07/1.01\%) to $21 \mathrm{~d}$ of age. In Exp. 2, one-d-old male KND were received and fed commercial starter diet from hatching to $21 \mathrm{~d}$ of age, and then divided into five groups with six replicates and fed one of five diets varying levels of lysine, TSAA, and threonine (T1, 0.73/0.62/0.54\%; T2, 0.80/0.68/0.60\%; T3, 0.87/0.74/0.65\%; T4, $0.94 / 0.80 / 0.70 \%$; T5, 1.01/0.86/0.75\%) during 22 to $56 \mathrm{~d}$ of age, respectively. The BW gain was linearly increased as dietary limiting AA levels increased to $1.20 \%$ lysine, $0.98 \%$ TSAA and $0.93 \%$ threonine. There were no significant differences in feed intake, gain:feed and uniformity among groups. In Exp. 2, the BW gain and gain:feed were not affected by dietary limiting AA levels. There were no significant differences in carcass characteristics and meat quality among groups. The growth performance and carcass characteristics did not show the significant response to increasing dietary limiting AA levels in KND during 22 to $56 \mathrm{~d}$ of age. In conclusion, the levels of lysine, TSAA and threonine necessary to maximize growth for starter phase were at least $1.20 \%, 0.98 \%$, and $0.93 \%$, respectively. On the other hands, KND require relatively low levels of limiting AA for late growth and carcass yield. The dietary levels of $0.73 \%$ lysine, $0.62 \%$ TSAA and $0.54 \%$ threonine appear to be adequate during growing phase. (Key Words: Limiting Amino Acids, Growth Performance, Carcass Characteristic, Growing Stage, Korean Native Ducks)
\end{abstract}

\section{INTRODUCTION}

Korean native ducks (KND, Anas platyrhynchos) have colored-feathers and unique meat flavor and texture with better fatty acid profiles (Muhlisin et al., 2013). But they show relatively slow-growth with poor feed conversion rate (Hong et al., 2012) and are reared more longer period (8 wk) as compared to imported commercial breeds (Kim et al., 2012). The commercial breeds are one of the fastest growing and capable of a feed efficiency of $45 \mathrm{~g}$ of BW gain per $100 \mathrm{~g}$ feed consumption with $3,100 \mathrm{~g} \mathrm{BW}$ at $42-\mathrm{d}$

\footnotetext{
* Corresponding Author: B. K. An. Tel: +82-2-450-3294, Fax: +82-2-452-9946, E-mail: abk7227@hanmail.net

${ }^{1}$ Poultry Science Division, National Institute of Animal Science, RDA, Seonghwan 330-801, Korea.

${ }^{2}$ Department of Animal Products and Food Science, Kangwon National University, Chuncheon 200-701, Korea.

Submitted Oct. 25, 2013; Accepted Dec. 17, 2013; Revised Jan. 20, 2014
}

old (Adeola, 2003). This suggests the possible differences in energy and nutrients needs between KND and commercial breeds from foreign breeding companies.

Methionine, lysine and threonine are considered to be most limiting amino acids (AA) in fast growing commercial ducks fed practical corn-soybean meal based diets (Adeola, 2006). To support the maximum growth and meat yield of ducks, adequate levels of these AA should be provided (Elkin, 1987). The BW and breast meat yield showed significant response to increasing dietary methionine contents in White Pekin ducks from 21 to $49 \mathrm{~d}$ of age (Xie et al., 2006). With increasing dietary lysine levels, growth performance and meat yield in growing male Pekin ducking were also significantly increased (Bons et al., 2002). Several experiments on the responses of commercial ducks to dietary AA have been conducted, but only limited information is available on the dietary most limiting AA needs in KND. These studies were conducted to exam the 
optimal levels of dietary limiting AA for growth and carcass characteristics during starter and grower periods as an initial nutrient study in KND.

\section{MATERIALS AND METHODS}

\section{Animals, diets, and management}

The male Korean native ducklings were received on the day of hatch from a local hatchery, individually weighed and randomly assigned into five dietary treated groups. A total of 450 ducklings were assigned into five groups with six replicates and fed one of five diets varying levels of lysine, total sulfur amino acids (TSAA) and threonine with consistent balance (T1: $0.90 \%, 0.74 \%$, and $0.70 \%$; T2: $1.00 \%, 0.82 \%$, and $0.77 \%$; T3: $1.10 \%, 0.90 \%$, and $0.85 \%$; T4: $1.20 \%, 0.98 \%$, and $0.93 \%$; T5: $1.30 \%, 1.07 \%$, and $1.01 \%$ ), for $21 \mathrm{~d}$ as shown in Table 1 . The experimental diets were formulated to meet and exceed the nutrients requirements of NRC (1994) and Korean feeding standard for poultry (2012) and processed as crumble form. The diets and water were provided for ad libitum intake. The ducklings were initially reared at $33^{\circ} \mathrm{C}$, and the room temperature was gradually decreased by $4^{\circ} \mathrm{C}$ weekly until a final temperature of $22^{\circ} \mathrm{C}$ was reached. Lighting was kept at 23/1 light/dark cycle throughout the experimental period. The BW and feed intake on a pen basis were recorded weekly and gain:feed was calculated.

In Exp. 2, one-d-old male Korean native ducklings were received and fed commercial starter diet $(21 \% \mathrm{CP}, 3,000$ $\mathrm{kcal}$ of $\mathrm{TMEn} / \mathrm{kg}$ ) from hatching to $21 \mathrm{~d}$ of age. All ducklings were weighed individually and randomly assigned into five dietary treated groups with six replicates. A total of 450 21-d-old ducklings were fed one of five diets with varying levels of lysine, TSAA and threonine with consistent balance (T1: $0.73 \%, 0.62 \%$, and $0.54 \%$; T2: $0.80 \%, 0.68 \%$, and $0.60 \%$; T3: $0.87 \%, 0.74 \%$, and $0.65 \%$;

Table 1. Feed formula and chemical composition of experimental diets, as-fed basis (Exp.1) ${ }^{1}$

\begin{tabular}{|c|c|c|c|c|c|}
\hline Items & $\mathrm{T} 1$ & $\mathrm{~T} 2$ & $\mathrm{~T} 3$ & $\mathrm{~T} 4$ & $\mathrm{~T} 5$ \\
\hline \multicolumn{6}{|l|}{ Ingredients } \\
\hline Yellow corn & 48.97 & 49.13 & 49.40 & 49.74 & 50.08 \\
\hline Soybean meal (47\% CP) & 20.00 & 20.00 & 19.73 & 19.04 & 18.35 \\
\hline Corn gluten meal $(60 \% \mathrm{CP})$ & 5.75 & 5.33 & 5.00 & 5.00 & 5.00 \\
\hline Canola meal, & 3.00 & 3.00 & 3.00 & 3.00 & 3.00 \\
\hline Wheat bran & 10.00 & 10.00 & 10.00 & 10.00 & 10.00 \\
\hline Dried distiller's grains with solubles & 5.00 & 5.00 & 5.00 & 5.00 & 5.00 \\
\hline Tallow & 3.00 & 3.00 & 3.00 & 3.00 & 3.00 \\
\hline Aluminosillicate & 0.50 & 0.50 & 0.50 & 0.50 & 0.50 \\
\hline Poultry vitamin $\operatorname{mix}^{2}$ & 0.15 & 0.15 & 0.15 & 0.15 & 0.15 \\
\hline L-lysine- $\mathrm{HCl}(78 \%)$ & - & 0.12 & 0.27 & 0.42 & 0.57 \\
\hline DL-methionine (99\%) & - & 0.09 & 0.19 & 0.28 & 0.37 \\
\hline L-threonine (98\%) & - & 0.038 & 0.136 & 0.224 & 0.318 \\
\hline Dicalcium phophate & 1.85 & 1.85 & 1.85 & 1.86 & 1.86 \\
\hline Limestone & 1.26 & 1.26 & 1.26 & 1.26 & 1.26 \\
\hline Poultry mineral $\operatorname{mix}^{3}$ & 0.15 & 0.15 & 0.15 & 0.15 & 0.15 \\
\hline Choline-Cl (50\%) & 0.07 & 0.07 & 0.07 & 0.08 & 0.08 \\
\hline Salt & 0.30 & 0.30 & 0.30 & 0.30 & 0.30 \\
\hline \multicolumn{6}{|l|}{ Calculated composition } \\
\hline TMEn (kcal/kg) & 2,900 & 2,900 & 2,900 & 2,900 & 2,900 \\
\hline $\mathrm{CP}(\%)$ & 20.00 & 20.00 & 20.00 & 20.00 & 20.00 \\
\hline $\mathrm{Ca}(\%)$ & 1.00 & 1.00 & 1.00 & 1.00 & 1.00 \\
\hline Available P (\%) & 0.45 & 0.45 & 0.45 & 0.45 & 0.45 \\
\hline Lysine (\%) & 0.90 & 1.00 & 1.10 & 1.20 & 1.30 \\
\hline Methionine (\%) & 0.37 & 0.46 & 0.54 & 0.63 & 0.71 \\
\hline Total sulfur amino acids (TSAA, \%) & 0.74 & 0.82 & 0.90 & 0.98 & 1.07 \\
\hline Threonine (\%) & 0.70 & 0.77 & 0.85 & 0.93 & 1.01 \\
\hline
\end{tabular}

${ }^{1}$ T1: $0.90 \%$ lysine/0.74\% TSAA/0.70\% threonine; T2: $1.00 \%$ lysine/0.82\% TSAA/0.77\% threonine; T3: $1.10 \%$ lysine/0.90\% TSAA/0.85\% threonine; T4: $1.20 \%$ lysine/0.98\% TSAA/0.93\% threonine; T5: $1.30 \%$ lysine/1.07\% TSAA/1.01\% threonine.

${ }^{2}$ Vitamin mixture provided the following nutrients per $\mathrm{kg}$ of diet: vitamin $\mathrm{A}, 14,000 \mathrm{IU}$; vitamin $\mathrm{D}_{3}$, 3,000 IU; vitamin E, 40 IU; vitamin $\mathrm{K}_{3}$, $24 \mathrm{mg}$; vitamin $\mathrm{B}_{1}, 12 \mathrm{mg}$; vitamin $\mathrm{B}_{2}, 5 \mathrm{mg}$; vitamin $\mathrm{B}_{6}, 3 \mathrm{mg}$; vitamin $\mathrm{B}_{12}, 0.02 \mathrm{mg}$; Biotin, $0.07 \mathrm{mg}$; Pantothenic acid, $10 \mathrm{mg}$; Folic acid, $5 \mathrm{mg}$; Nicotinic acid, $40 \mathrm{mg}$.

${ }^{3}$ Mineral mixture provided the following nutrients per kg: Fe, $90 \mathrm{mg}\left(\right.$ as $\mathrm{FeSO}_{4} \mathrm{H}_{2} \mathrm{O}$ ); $\mathrm{Zn}, 145 \mathrm{mg}\left(\right.$ as $\mathrm{ZnSO}_{4} \mathrm{H}_{2} \mathrm{O}$ ); $\mathrm{Mn}, 180 \mathrm{mg}\left(\right.$ as $\mathrm{MnSO}_{4} \mathrm{H}_{2} \mathrm{O}$ ); $\mathrm{Co}, 1.5$ mg (as $\left.\mathrm{CoSO}_{4} \mathrm{H}_{2} \mathrm{O}\right) ; \mathrm{Cu}, 24 \mathrm{mg}\left(\right.$ as $\left.\mathrm{CuSO}_{4} \mathrm{H}_{2} \mathrm{O}\right)$; $\mathrm{Se}, 0.7 \mathrm{mg}\left(\right.$ as $\left.\mathrm{Na}_{2} \mathrm{SeO}_{3}\right) ; \mathrm{I}, 2 \mathrm{mg}\left(\right.$ as $\mathrm{Ca}\left(\mathrm{IO}_{3}\right)_{2} \mathrm{H}_{2} \mathrm{O}$. 
T4: $0.94 \%, 0.80 \%$, and $0.70 \%$; T5: $1.01 \%, 0.86 \%$, and $0.75 \%$ ), for $35 \mathrm{~d}$ (Table 2). The experimental diets were formulated to meet and exceed the nutrients requirements of NRC (1994) and Korean feeding standard for poultry (2012) and processed as pellet form. The diets and water were provided for ad libitum intake. The BW and feed intake on a pen basis were recorded weekly and gain:feed was also calculated.

\section{Sampling and measurements}

At the end of the experimental period, eight ducks per each treatment were selected and weighed individually. The ducks selected were sacrificed by neck cut, scalded with hot water $\left(60^{\circ} \mathrm{C}\right.$ for $\left.3 \mathrm{~min}\right)$, and removed the feathers mechanically. Carcasses were eviscerated manually and portioned into commercial cuts such as neck, breast, leg and wing. The breasts were immediately chilled for $30 \mathrm{~min}$ in ice water and transferred to icebox and then prepared separately for further analyses. All animal care procedures were approved by Institutional Animal Care and Use Committee in Konkuk University.

The instrumental color of fresh meat, including lightness $\left(\mathrm{L}^{*}\right)$, redness $\left(\mathrm{a}^{*}\right)$ and yellowness $\left(\mathrm{b}^{*}\right)$, were measured using a chromameter (CR 210, Minolta, Japan). The $\mathrm{pH}$ values of breast meats were estimated in triplicate with a $\mathrm{pH}$ meter (340 Mettler-Toledo, Switzerland). Briefly, $1 \mathrm{~g}$ of breast meat was cut into small pieces and homogenized with $9 \mathrm{~mL}$ of distilled water for $1 \mathrm{~min}$ in an Ultra-Turrax (Model No. T25, Janken and Kunkel, Germany). To determine the cooking loss, $60 \mathrm{~g}$ of breast meat was boiled individually in polyethylene bags immersed in $80^{\circ} \mathrm{C}$ water bath for $30 \mathrm{~min}$ and cooled at room temperature for $30 \mathrm{~min}$. The cooking loss was calculated from the weights of uncooked and cooked meats. The water holding capacity (WHC) was estimated according to filter paper pressed method (Grau and Hamm, 1953). Breast meat

Table 2. Feed formula and chemical composition of experimental diets, as-fed basis (Exp. 2) ${ }^{1}$

\begin{tabular}{|c|c|c|c|c|c|}
\hline Items & $\mathrm{T} 1$ & $\mathrm{~T} 2$ & $\mathrm{~T} 3$ & $\mathrm{~T} 4$ & $\mathrm{~T} 5$ \\
\hline \multicolumn{6}{|l|}{ Ingredients } \\
\hline Yellow corn & 56.75 & 58.00 & 59.08 & 59.08 & 59.08 \\
\hline Soybean meal (47\% CP) & 11.38 & 12.57 & 15.32 & 14.69 & 14.07 \\
\hline Corn gluten meal $(60 \% \mathrm{CP})$ & 6.00 & 6.00 & 5.01 & 5.05 & 5.08 \\
\hline Canola meal & - & - & - & - & - \\
\hline Wheat bran & 12.50 & 12.00 & 10.06 & 10.40 & 10.75 \\
\hline Dried distiller's grains with solubles & 6.00 & 4.00 & 3.00 & 3.00 & 3.00 \\
\hline Tallow & 3.08 & 3.00 & 3.00 & 3.00 & 3.00 \\
\hline Aluminosillicate & 0.50 & 0.50 & 0.50 & 0.50 & 0.50 \\
\hline Poultry vitamin $\operatorname{mix}^{2}$ & 0.12 & 0.12 & 0.12 & 0.12 & 0.12 \\
\hline L-lysine-HCl (78\%) & 0.13 & 0.18 & 0.20 & 0.31 & 0.42 \\
\hline DL-methionine (99\%) & - & 0.05 & 0.12 & 0.18 & 0.25 \\
\hline L-threonine (98\%) & - & 0.010 & 0.041 & 0.100 & 0.160 \\
\hline Dicalcium phophate & 1.33 & 1.35 & 1.37 & 1.37 & 1.37 \\
\hline Limestone & 1.68 & 1.67 & 1.63 & 1.65 & 1.65 \\
\hline Poultry mineral mix $^{3}$ & 0.12 & 0.12 & 0.12 & 0.12 & 0.12 \\
\hline Choline-Cl (50\%) & 0.13 & 0.13 & 0.13 & 0.13 & 0.13 \\
\hline Salt & 0.28 & 0.30 & 0.30 & 0.30 & 0.30 \\
\hline \multicolumn{6}{|l|}{ Calculated composition } \\
\hline TMEn (kcal/kg) & 3,050 & 3,050 & 3,050 & 3,050 & 3,050 \\
\hline $\mathrm{CP}(\%)$ & 17.00 & 17.00 & 17.00 & 17.00 & 17.00 \\
\hline $\mathrm{Ca}(\%)$ & 1.00 & 1.00 & 1.00 & 1.00 & 1.00 \\
\hline Available P (\%) & 0.35 & 0.35 & 0.35 & 0.35 & 0.35 \\
\hline Lysine $(\%)$ & 0.73 & 0.80 & 0.87 & 0.94 & 1.01 \\
\hline Methionine (\%) & 0.32 & 0.37 & 0.43 & 0.49 & 0.56 \\
\hline Total sulfur amino acids (TSAA, \%) & 0.62 & 0.68 & 0.74 & 0.80 & 0.86 \\
\hline Threonine (\%) & 0.54 & 0.60 & 0.65 & 0.70 & 0.75 \\
\hline
\end{tabular}

${ }^{1}$ T1: $0.73 \%$ lysine/ $0.62 \%$ TSAA/0.54\% threonine; T2: $0.80 \%$ lysine/0.68\% TSAA/0.60\% threonine; T3: $0.87 \%$ lysine/0.74\% TSAA/0.65\% threonine; T4: $0.94 \%$ lysine $/ 0.80 \%$ TSAA $/ 0.70 \%$ threonine; T5, $1.01 \%$ lysine $/ 0.86 \%$ TSAA/ $0.75 \%$ threonine.

${ }^{2}$ Vitamin mixture provided the following nutrients per kg of diet: vitamin A, 11,000 IU; vitamin $\mathrm{D}_{3}, 2,400 \mathrm{IU}$; vitamin E, $32 \mathrm{IU}$; vitamin $\mathrm{K}_{3}, 20 \mathrm{mg}$; vitamin $\mathrm{B}_{1}, 10 \mathrm{mg}$; vitamin $\mathrm{B}_{2}, 4 \mathrm{mg}$; vitamin $\mathrm{B}_{6}, 2.4 \mathrm{mg}$; vitamin $\mathrm{B}_{12}, 0.02 \mathrm{mg}$; Biotin, $0.06 \mathrm{mg}$; Pantothenic acid, $8 \mathrm{mg}$; Folic acid, $4 \mathrm{mg}$; Nicotinic acid, $32 \mathrm{mg}$.

${ }^{3}$ Mineral mixture provided the following nutrients per kg: $\mathrm{Fe}, 72 \mathrm{mg}\left(\right.$ as $\mathrm{FeSO}_{4} \mathrm{H}_{2} \mathrm{O}$ ); $\mathrm{Zn}, 115 \mathrm{mg}\left(\right.$ as $\left.\mathrm{ZnSO}_{4} \mathrm{H}_{2} \mathrm{O}\right) ; \mathrm{Mn}, 145 \mathrm{mg}\left(\right.$ as $\left.\mathrm{MnSO}{ }_{4} \mathrm{H}_{2} \mathrm{O}\right) ; \mathrm{Co}_{0}, 1.2$ $\mathrm{mg}\left(\right.$ as $\left.\mathrm{CoSO}_{4} \mathrm{H}_{2} \mathrm{O}\right) ; \mathrm{Cu}, 20 \mathrm{mg}\left(\right.$ as $\left.\mathrm{CuSO}_{4} \mathrm{H}_{2} \mathrm{O}\right) ; \mathrm{Se}, 0.5 \mathrm{mg}\left(\right.$ as $\left.\mathrm{Na}_{2} \mathrm{SeO}_{3}\right) ; \mathrm{I}, 1.6 \mathrm{mg}\left(\right.$ as $\mathrm{Ca}_{(}\left(\mathrm{IO}_{3}\right)_{2} \mathrm{H}_{2} \mathrm{O}$. 
Table 3. Growth performance and uniformity of Korean native male ducks fed diets with varying levels of limiting amino acids during 0 to $21 \mathrm{~d}^{1}$ (Exp. 1)

\begin{tabular}{|c|c|c|c|c|c|}
\hline & $\begin{array}{c}\text { Final BW } \\
\text { (g/bird) }\end{array}$ & $\begin{array}{l}\text { BW gain } \\
\text { (g/d/bird) }\end{array}$ & Gain:feed & $\begin{array}{l}\text { Feed intake } \\
\text { (g/d/bird) }\end{array}$ & $\begin{array}{c}\text { Uniformity } \\
(\%)\end{array}$ \\
\hline \multicolumn{6}{|c|}{ Levels of Lys/TSAA ${ }^{2} / \mathrm{Thr}(\%)$} \\
\hline $0.90 / 0.74 / 0.70$ & $1,080.1$ & 46.91 & 0.535 & 88.7 & 61.75 \\
\hline $1.00 / 0.82 / 0.77$ & $1,112.6$ & 48.40 & 0.549 & 87.9 & 68.50 \\
\hline $1.10 / 0.90 / 0.85$ & $1,123.6$ & 48.89 & 0.559 & 87.6 & 69.75 \\
\hline $1.20 / 0.98 / 0.93$ & $1,147.3$ & 49.97 & 0.538 & 92.9 & 65.00 \\
\hline $1.30 / 1.07 / 1.01$ & $1,137.3$ & 49.52 & 0.559 & 87.9 & 62.00 \\
\hline SEM & 15.51 & 0.71 & 0.02 & 1.25 & 0.08 \\
\hline \multicolumn{6}{|l|}{ Probability } \\
\hline Linear & 0.0075 & 0.0076 & 0.07 & 0.39 & 0.91 \\
\hline Quadratic & 0.23 & 0.23 & 0.50 & 0.53 & 0.43 \\
\hline
\end{tabular}

${ }^{\mathrm{T}}$ Each least squares mean represents 6 observations. ${ }^{2}$ TSAA $=$ Total sulfur amino acids.

( $0.3 \mathrm{~g}$ ) was weighed on a Whatman filter paper (No. 2, UK). The samples were pressed between two plexiglass plates for $3 \mathrm{~min}$. The areas of pressed sample and water were measured using planimeter (Super Planix $\alpha$, Tayama Technic Inc., Japan).

\section{Statistical analysis}

Obtained data were analyzed as a CRD by using the GLM procedure of SAS software (SAS, 2002). The linear and quadratic models were analyzed by the REG procedure of SAS software (SAS, 2002). Statistical significance was accepted at $\mathrm{p}<0.05$.

\section{RESULTS AND DISCUSSION}

Growth performance and uniformity of KND fed diets with varying levels of limiting AA during starter phase are presented in Table 3. Ducklings fed diet with higher levels of limiting AA grew faster than the lowest limiting AA group $(p<0.05)$. There were no significant differences in gain:feed, feed intake and uniformity among groups. Table 4 shows the growth performance and uniformity of KND fed diets with varying levels of limiting AA during 22 to 56 $d$ of age. There were no significant linear and quadratic trends of dietary limiting AA levels affecting final BW and BW gain. The gain:feed, feed intake and uniformity were not affected by dietary levels of limiting AA. The optimal dietary levels of lysine, TSAA and threonine for grower phase of KND were $0.73 \%, 0.62 \%$, and $0.54 \%$, respectively.

In duck diets formulated with corn and soybean meal, methionine, lysine and threonine are likely to be the most limiting AA (Elkin, 1987). The commercial ducks are one of the fastest growing and to support the maximum growth and meat yield of ducks, adequate levels of these AA should be provided (Adeola, 2003). It was reported that the growth of commercial meat-type ducks was significantly improved with increasing levels of dietary lysine (Bons et al., 2002) and methionine (Xie et al., 2006). In this study, a significant linear trend for final $\mathrm{BW}$ and daily $\mathrm{BW}$ gain was determined with increasing dietary limiting AA levels during starter phase. But, the late growth of KND was not affected by dietary levels of lysine, TSAA and threonine. It is assumed that there is considerable difference in growth response, especially late growth, according to dietary

Table 4. Growth performance and uniformity of Korean native male ducks fed diets with varying levels of limiting amino acids during 22 to $56 \mathrm{~d}^{1}$ (Exp. 2)

\begin{tabular}{lccccc}
\hline & $\begin{array}{c}\text { Final BW } \\
(\mathrm{g} / \mathrm{bird})\end{array}$ & $\begin{array}{c}\text { BW gain } \\
(\mathrm{g} / \mathrm{d} / \mathrm{bird})\end{array}$ & Gain:feed & $\begin{array}{c}\text { Feed intake } \\
(\mathrm{g} / \mathrm{d} / \mathrm{bird})\end{array}$ & $\begin{array}{c}\text { Uniformity } \\
(\%)\end{array}$ \\
\hline $\begin{array}{l}\text { Levels of Lys/TSAA } / \text { Thr }(\%) \\
\text { 0.73/0.62/0.54 }\end{array}$ & & & & & \\
$0.80 / 0.68 / 0.60$ & $2,975.8$ & 53.36 & 0.218 & 244.0 & 79.00 \\
$0.87 / 0.74 / 0.65$ & $3,012.5$ & 54.47 & 0.222 & 245.2 & 72.75 \\
$0.94 / 0.80 / 0.70$ & $2,984.5$ & 53.62 & 0.219 & 243.4 & 68.75 \\
$1.01 / 0.86 / 0.75$ & $3,042.3$ & 55.27 & 0.223 & 247.6 & 79.25 \\
SEM & $3,041.8$ & 55.24 & 0.218 & 251.9 & 77.25 \\
Probability & 35.87 & 1.02 & 0.05 & 5.74 & 0.06 \\
$\quad$ Linear & & & & 0.32 & \\
Quadratic & 0.17 & 0.17 & 0.90 & 0.57 & 0.88 \\
\hline
\end{tabular}

${ }^{1}$ Each least squares mean represents 6 observations. ${ }^{2}$ TSAA $=$ Total sulfur amino acids. 
Table 5. Mean yield of carcass and major component parts of Korean native male ducks fed diets with varying levels of limiting amino acids during 22 to $56 \mathrm{~d}^{1}$ (Exp. 2)

\begin{tabular}{|c|c|c|c|c|c|}
\hline & Carcass $(\%)$ & Liver & Abdominal fat & Right breast & Right leg \\
\hline & & --- & -------- g/10 & 3W ---.-- & ---- \\
\hline \multicolumn{6}{|c|}{ Levels of Lys/TSAA ${ }^{2} / \mathrm{Thr}(\%)$} \\
\hline $0.73 / 0.62 / 0.54$ & 67.86 & 1.42 & 1.09 & 5.14 & 6.63 \\
\hline $0.80 / 0.68 / 0.60$ & 69.65 & 1.47 & 1.28 & 5.74 & 6.54 \\
\hline $0.87 / 0.74 / 0.65$ & 68.62 & 1.33 & 1.11 & 5.63 & 6.40 \\
\hline $0.94 / 0.80 / 0.70$ & 68.80 & 1.36 & 1.06 & 5.59 & 6.88 \\
\hline $1.01 / 0.86 / 0.75$ & 69.10 & 1.44 & 1.36 & 5.22 & 6.94 \\
\hline SEM & 0.68 & 0.05 & 0.17 & 0.14 & 0.18 \\
\hline \multicolumn{6}{|l|}{ Probability } \\
\hline Linear & 0.54 & 0.69 & 0.55 & 0.97 & 0.10 \\
\hline Quadratic & 0.43 & 0.23 & 0.60 & 0.0015 & 0.17 \\
\hline
\end{tabular}

${ }^{1}$ Each least squares mean represents 8 observations. ${ }^{2}$ TSAA $=$ Total sulfur amino acids.

limiting AA levels between KND and commercial breeds.

In this study, the levels of lysine, TSAA and threonine necessary to maximize growth were at least $1.20 \%, 0.98 \%$, and $0.93 \%$, respectively for starter phase. The dietary levels of $0.73 \%$ lysine, $0.62 \%$ TSAA and $0.54 \%$ threonine appear to be adequate during growing phase. These are lower than corresponding values suggested by breeding company for commercial meat-type ducks (Grimaud Fréres Selection, 1995). The duck industry continues to feed more limiting AA intake because of concern of underfeeding for maximal growth and optimal feed conversion rate. During late growing stage, the levels of dietary lysine, TSAA and threonine for commercial ducks in the industry ranges from $0.87 \%, 0.74 \%$, and $0.65 \%$ to $1.01 \%, 0.86 \%$, and $0.75 \%$, respectively and is clearly above the levels suggested by NRC (1994) and Korea feeding standard (2012). Dietary protein and AA are a major cost and optimal level is important for lowering feed cost per unit of duck product. In present study, KND require relatively low levels of most limiting AA for late growth and carcass yield due to low daily weight gain. This information on limiting AA need will enable more accurate and economic diet formulation and great control on dietary nutritional quality for KND.

Mean yield of carcass and major component parts of KND fed diets with varying levels of limiting AA are presented in Table 5. The carcass yield and relative weights of various organs were not affected by dietary levels of limiting AA, except for breast yield. There were no significant linear and quadratic trends of dietary limiting AA levels affecting color and $\mathrm{pH}$ of breast meats. The cooking loss and WHC were not also affected by dietary levels of limiting AA (Table 6).

The WHC of breast meat in KND was ranged from $46.25 \%$ to $47.58 \%$, which agreed with our previous result (Muhlisin et al., 2013). There is increasing preference for indigenous breeds called quality poultry meat over the fastgrowing breeds developed from commercial breeding companies. The taste attributes of the cooked breast from KND scored higher than corresponding part from commercial meat-type ducks, according to the sensory

Table 6. Physico-chemical properties of breast meats of Korean native male ducks fed diets with varying levels of limiting amino acids during 22 to $56 \mathrm{~d}^{1}$ (Exp. 2)

\begin{tabular}{|c|c|c|c|c|c|c|}
\hline & \multicolumn{3}{|c|}{ Meat color $(\mathrm{CIE})^{2}$} & \multirow{2}{*}{$\mathrm{pH}$} & \multirow{2}{*}{$\begin{array}{c}\text { Cooking loss } \\
(\%)\end{array}$} & \multirow{2}{*}{$\begin{array}{c}\mathrm{WHC}^{3} \\
(\%)\end{array}$} \\
\hline & $\mathrm{L}^{*}$ & $a^{*}$ & $b^{*}$ & & & \\
\hline \multicolumn{7}{|c|}{ Levels of Lys/TSAA ${ }^{4} / \mathrm{Thr}(\%)$} \\
\hline $0.73 / 0.62 / 0.54$ & 46.94 & 11.16 & 4.59 & 6.08 & 37.69 & 47.12 \\
\hline $0.80 / 0.68 / 0.60$ & 46.48 & 11.20 & 4.44 & 6.07 & 35.13 & 47.09 \\
\hline $0.87 / 0.74 / 0.65$ & 45.68 & 11.76 & 4.31 & 6.08 & 37.68 & 46.25 \\
\hline $0.94 / 0.80 / 0.70$ & 47.43 & 11.65 & 4.20 & 6.05 & 36.08 & 47.58 \\
\hline $1.01 / 0.86 / 0.75$ & 47.28 & 11.25 & 3.89 & 6.07 & 35.29 & 46.58 \\
\hline SEM & 1.36 & 0.63 & 1.33 & 0.03 & 1.18 & 1.35 \\
\hline \multicolumn{7}{|l|}{ Probability } \\
\hline Linear & 0.71 & 0.77 & 0.72 & 0.67 & 0.31 & 0.89 \\
\hline Quadratic & 0.55 & 0.53 & 0.96 & 0.88 & 0.89 & 0.96 \\
\hline
\end{tabular}

${ }^{1}$ Each least squares mean represents 8 observations.

${ }^{2} \mathrm{CIE}=$ Commission Internationale de l'Eclairage $\mathrm{L}^{*}=$ lghtness, $\mathrm{a}^{*}=$ redness, $\mathrm{b}^{*}=$ yellowness.

${ }^{3} \mathrm{WHC}=$ Water holding capacity. ${ }^{4} \mathrm{TSAA}=$ Total sulfur amino acids. 
evaluation by panels (Muhlisin et al., 2013). In order to diversify duck meats to take account of consumer's demands, it is necessary to clarify the nutritional values of KND meats.

In conclusion, a significant linear trend for daily BW gain was determined with increasing dietary limiting AA levels during starter phase. But, KND require relatively low levels of most limiting AA for late growth stage due to slow-growth characteristics.

\section{ACKNOWLEDGEMENT}

This research was supported by a grant from National Institute of Animal Science, RDA.

\section{REFERENCES}

Adeola, O. 2003. Recent advances in duck nutrition. In: Proceedings of the 24th Western Nutrition Conference, Winnipeg, Manitoba, Canada, pp. 191-204.

Adeola, O. 2006. Review of research in duck nutrient utilization. Int. J. Poult. Sci. 5:201-208.

Bons, A., R. Timmler, and H. Jeroch. 2002. Lysine requirement of growing male Pekin ducks. Br. Poult. Sci. 43:677-686.

Elkin, R. G. 1987. A review of duck nutrition research. World's Poult. Sci. J. 43:84-106.
Grau, R. and R. A. Hamm. 1953. A simple method for the determination of water binding in muscles. Naturwissenschaften 40:29-30.

Grimaud Fréres Selection. 1995. Rearing guide roasting pekin ducks: Technical guide Pekin broiler duck. http://www.grimaudfreres.com Accessed February 2007

Hong, E. C., H. J. Choo, B. S. Kang, C. D. Kim, K. N. Heo, M. J. Lee, J. Hwangbo, O. S. Suh, H. C. Choi, and H. K. Kim. 2012. Performance of growing period of large-type Korean native ducks. Korean J. Poult. Sci. 39:143-149.

Kim, H. K., B. S. Kang, J. Hwangbo, C. D. Kim, K. N. Heo, H. J. Choo, D. S. Park, O. S. Suh, and E. C. Hong. 2012. The study on growth performance and carcass yield of meat-type Korean native ducks. Korean J. Poult. Sci. 39:45-52.

Korean Feeding Standard for Poultry. 2012. Nutrient Requirement of Poultry. National Institute of Animal Science, RDA, Suwon, Korea.

Muhlisin, M., D. S. Kim, Y. R. Song, H. R. Kim, H. J. Kwon, B. K. An, C. W. Kang, H. K. Kim, and S. K. Lee. 2013. Comparison of meat characteristics between Korean native duck and imported commercial duck raised under identical rearing and feeding condition. Korean J. Food Sci. Anim. Resour. 33:89-95. National Research Council. 1994. Nutrient Requirement of Poultry. 9th revised edn. National Academic Press, Washington, DC.

SAS. 2002. SAS Software for PC. Release 9.1, SAS Institute Inc., Cary, North Carolina, USA.

Xie, M., S. S. Hou, and W. Huang. 2006. Methionine requirements of male white Peking ducks from twenty-one to forty-nine days of age. Poult. Sci. 85:743-746. 